\title{
Evaluating the Sino-Tibeto-Austronesian Hypothesis
}

\begin{abstract}
This paper analyses and evaluates the alleged genetic relationship between Sino-Tibetan and Austronesian, proposed by the French sinologist Laurent Sagart. The aim of the following paper is neither to prove, nor to disprove the Sino-Tibeto-Austronesian superphylum but to argue whether the data presented in favour of this proposed genetic relationship do or do not stand the scrutiny of a historical linguist. This paper also considers the hypothetical homeland of Proto-Sino-Tibeto-Austronesian people, with an eye towards competing hypotheses, such as Sino-Indo-European. It is concluded that Sagart's approach may be insufficient for proof of controversial cases of disputed genetic relationship, given the non-obvious relatedness of the languages he is comparing.
\end{abstract}

Keywords: Sino-Tibeto-Austronesian hypothesis; Sino-Tibetan languages; genetic relationship of languages; comparative method.

\begin{abstract}
"Der erste mir bekannte Sprachvergleicher im heutigen Sinne des Wortes ist der gelehrte Holländer Hadr. Relandus, der in seinem Dissertationes miscellaneae, Utrecht 1706-08, die weite Verbreitung des malaischen Sprachstammes, sogar Lautvertretunsgesetze zwischen Malaisch und Madegassisch nachweist" [Georg von der Gabelentz, Die Sprachwissenschaft: ihre Aufgaben, Methoden, und bisherigen Ergebnisse, 1891, p. 26].
\end{abstract}

\section{Historical overview}

Since the beginning of Western scholarly interest in both Sino-Tibetan and Austronesian, a panoply of claims concerning a wider genetic relationship of these language families has been proposed until our days. Among these various proposals, ranging from quasi-scholarly publications to more serious works, we may remember (1) the Austric hypothesis, first proposed by Schmidt (1906) and then re-proposed by Reid (1994); (2) the "Indo-Chinese" hypothesis of Conrady (1896, 1916); (3) the Sino-Caucasian hypothesis of Starostin (1984, 1989, 1991, 2005); (4) the Sino-Indo-European argued for by Ulenbrook (1967) and Pulleyblank (1995ab, 1996), and somewhat reinforced by Beckwith (2002); (5) the Sapirian Sino-Dene hypothesis (1915), further strengthened by Shafer (1952); (6) the Hokan-Austronesian hypothesis of Rivet (1925, 1926); (7) the Japanese-Austronesian hypothesis of Kawamoto (1977, 1978, 1980, 1984, 1993); (8) the Quechua-Austronesian hypothesis of Kempler-Cohen (2012); (9) the Sino-Austronesian hypothesis (Sagart 1993); (10) the Sino-Tibeto-Austronesian hypothesis (Sagart 2004, 2005, 2008, 2013, 2016). To be fair, it must be remembered that the Malayo-Polynesian languages, a subgroup of the Austronesian family, were originally drawn near the Indo-European family after the great German philosopher and linguist Wilhelm von Humboldt (1767-1835) noted that nearly half of the vocabulary of Kawi, the poetic language of the Old Javanese texts, derives from Sanskrit (1836-1839). ${ }^{1}$ Nevertheless, Humboldt did not explicitly claim that Ma-

\footnotetext{
${ }^{1}$ Campbell and Poser (2008: 61) applauded Humboldt's emphasis on grammatical structure. In their book they conclude that Humboldt determined Kawi as "Malayan" (Austronesian), in spite of the vocabulary of San-
} 
layo-Polynesian was a branch of Indo-European. Rather, this erroneous genetic relationship was argued for by Franz Bopp (1791-1867), who concluded that "[d]afs aber der Zufall bei allen diesen Wörtern sein Spiel getrieben habe, und bei allen anderen, die wir noch aus diesem Sprachgebiete dem Sanskrit gegenüberstellen können, ist unglaublich, zumal da bei einigen Wortklassen, nämlich bei den Pronominen und Zahlwörtern, worauf gerade bei Verwandtschaftsbestimmungen der Sprachen sehr viel ankommt, die Übereinstimmung fast durchgreifend erscheint" (1841: 7). Bopp's view of the linguistic facts was utterly rejected by von der Gabelentz (1891: 164), who wrote:

Es ist schrecklich verfürerisch in der Sprachenwelt umherzuschwärmen, drauf los Vocabeln zu vergleichen und dann die Wissenschaft mit einer Reihe neu entdeckter Verwandschaften zu beglücken. Es kommen auch schrecklich viele Dummheiten dabei heraus; denn allerwaertssind unmethodische Köpfe die vordringlichsten Entdecker.

It is extremely important to bear this chronology of facts in mind in our analysis of the Sino-Tibeto-Austronesian (STAN henceforth) hypothesis, because it illustrates one of the many illicit modifications of the standard comparative method. In other words, it tells us how the comparative method does not and therefore should not work.

We owe the attempt to prove that Chinese and Austronesian are genetically related to Sagart (1990). In its earliest version, the theory linked only Sinitic, not Tibeto-Burman, and it seems that this early proposal was greeted by harsh critiques from South-East Asian specialists. Sagart has since modified his views, and now considers Chinese related to both Tibeto-Burman and Austronesian. This later proposal was, nonetheless, greeted by yet another round of criticism both from Austronesianists (Blust 1995, Li 1995) and Sinologists (Wang 1995, Pulleyblank 1996). ${ }^{2}$ Leaving aside for a while the fact that any reader with at least half open mind would have to accept that something far more serious is afoot in the STAN than merely a few chance resemblances, the problem for some critics of the STAN (e.g. Pulleyblank 1996) is that their proposed explanation of the facts seems as implausible as their criticised linguistic scenario, perhaps even more so. ${ }^{3}$

In the following paragraphs, theories concerning the existence of the STAN superphylum and other relative problems - from basic lexicon to the question regarding the Urheimat will be independently discussed and evaluated.

\section{Methodological considerations}

If it is a truism in historical linguistics that shared paradigmatic morphology, intended as the combination of morphological markers in a string, is the most stable system and, thus, has the

skrit origin it contains. However, this is not exactly the opinion of Blust, who writes: "He noted the obvious fact that much of the vocabulary has been borrowed from Sanskrit, but suspected that under this layer of relatively recent borrowing was a deeper layer indicative of genetic relationship" (2013: 659). What emerges directly from Humboldt's work, however, is closer to Campbell \& Poser's depicted picture. Humboldt recognised the borrowings and, unlike Bopp, did not fall prey of lexical similarities. Rather, he utilised, as proof of kinship, both grammatical structures and sound correspondences (Humboldt 1836-9: 208-210, 217, 219-220, 221).

${ }^{2}$ STAN is partially accepted by Wolf (2010), who holds the view that Austronesian and Sino-Tibetan are two branches of the same "gigantophylum."

${ }^{3}$ On a personal note it should be premised that this author's opinion toward the so-called "long-range comparisons" is unbiased. The two most promising superphyla which exist today, according to this writer's opinion, are Indo-Uralic (Kortlandt 2010) and Yeniseic-Na-Dene, whose affiliation is prevalently built on paradigmatic morphology. 
the strongest probatory force, then it is also true that any proposal of genetic relationship, no matter whether short-ranged or long-ranged, starts with the identifications of cognate forms in basic lexicon. ${ }^{4}$ Starting from 1990, Sagart has been busy in providing Sino-Austronesian cognates, and in modifying or incrementing his earlier proposals. In one of his latest proposals (Sagart 2005), for example, Sagart has eliminated some of the false cognates which appeared in his early works, such as pú 脯, erroneously glossed as "breast." ${ }^{5}$ It is laudable that Sagart is not afraid of revising his positions when new information forces him to rethink a problem. Nevertheless, his newer sixty-one basic vocabulary comparisons between AN and Old Chinese ${ }^{6}$ (OC henceforth) still remain problematic.

First of all, it would be more accurate to compare Proto-Austronesian (PAN hereafter) forms with Proto-Sino-Tibetan (PST), because the addition of Tibeto-Burmese cognates can strengthen any lexical match between PAN and OC; conversely, if such cognates cannot be found, one would be more prone to interpret these lexical matches as a result of areal contacts between OC and PAN.7

${ }^{4}$ By "basic lexicon" is not necessarily meant, in this paper, the 100-word list proposed by Morrison Swadesh (1971). It must be remembered that this definition is not an absolute, and that in these years several scholars from the Moscow School have worked within this "paradigm," trying to separate the "more stable" part from its "less stable" counterpart. For further knowledge, the interested reader should consult Dolgopolsky (1964) and Starostin (1984, 1991). See also the Leizpig-Jakarta list (2009).

5 The Jiyùn clearly indicates that the meaning of this character, a somewhat dialectal form, should be "chicken breast." It follows that it does not match semantically the alleged Austronesian (AN hereafter) form riba.

${ }^{6}$ The very notion of "Old Chinese" is somewhat misleading. By Old Chinese is generally meant the language from the Early Zhōu (1046-771 BC) to the Western Hàn (206 BC-9 AD) period. Nevertheless terms such as "Old Chinese," "Middle Chinese," "Modern Chinese," etc. leave the reader with the impression of a linguistic unity in space and time throughout present-day Chinese territory, reinforced by certain lingering adumbrations of the somewhat involved and generally rather special political unity that has allegedly existed from then to now. In fact, the old "Chinese" language spoken by the Zhōu-not the earliest form of "Old Chinese" - was surely and undoubtedly different not only from the medieval language known as "Middle Chinese" but even from the so-called "Late Old Chinese" of the Hàn times. It is well-known that Hàn people, intended as the people of the Hàn dynasty - including its founder Liú Bāng-were descendant of Chǔ (1030 BCE-223), therefore it is not merely possible but very probable that Chǔ-Hàn Chinese (i.e. Late Old Chinese) was not only different from Zhōu Chinese (i.e. Early Old Chinese) but actually closer to Chǔ Chinese (i.e. the old language of the Elegies of Chǔ). Chǔ people were probably Hmong-Mien speakers, although the ruling class was undoubtedly Chinese-speaking. Middle Chinese is phonologically, typologically and lexically different from the Tibeto-Burman-looking Zhōu Chinese, let alone Shāng Chinese, and does not necessarily derive directly from the Old Chinese of the earliest classics (perhaps it comes from Chǔ-Hàn Chinese?). In this author's opinion, the situation is, more or less, identical to the situation of India or of Italy and Greece. The Romans in Latium were undeniably speaking Latin after the Latino-Faliscan conquest of the Italian Peninsula. Today the people of Rome are speaking, nonetheless, a language which we now call 'Italian.' We have opted to use this term because vulgar Latin has evolved into a number of different "languages," and not only into Italian, but this is a scholarly convenience. This is probably what happened in China. This view was somewhat presaged by Professor Branner, who writes that "early Chinese, the language of the classical texts, is perhaps truly a form of Tibeto-Burman; but medieval and modern Chinese belong to their own, distinct language family" (Branner 2000: 164). While this writer does not claim that Old Chinese and Middle Chinese are not related (they are and this fact is undeniable), we may agree on the fact that "the transition between early and medieval Chinese involved linguistic changes so fundamental that, for purposes of formal classification, we should consider the two types to have been different languages" (Ibid.).

${ }^{7}$ Elsewhere, Sagart (2011c) cites few PST reconstructions, but they are too few and not easily verifiable. It is

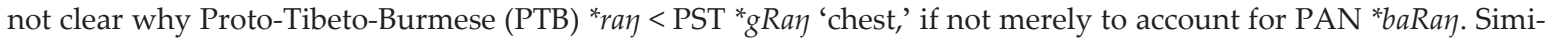

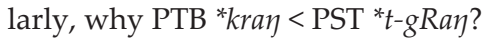


In addition, we must say that PAN was probably spoken during the sixth or fifth millennium BCE, while OC (which this author strongly suggests to rename as Zhōu Chinese) was spoken, more or less, in the second millennium BCE. This leaves a gap of three or two millennia after the purported split of Sinitic from its ancestor proto-language. Needless to say, many things may have happened in the meantime. Even assuming that the two language families are genetically related, one might expect the effects of coincidence, lookalikes and Wanderwörter to distort the evidence and create false positives. What if PAN and PST true commonalities had mutated separately beyond the point of being recognised as more akin to each other? Of course we cannot dismiss the entire STAN hypothesis with the argumentum ex silentio, but this is a serious problem which needs to be taken into consideration.

Furthermore, setting aside the fact that some Austronesianists (Li 1995, Blust 1995) have pointed out that PAN reconstructions do not belong to more general accepted reconstructed forms, another serious problem in this 61-word list is represented by the complete absence of numerals, pronouns, and basic kin terms. ${ }^{8}$ It is true that personal pronouns may have few marked sounds (and thus phonetic resemblance may just be fortuitous), but to make a point in favour of a genetic relationship without so much as including body parts, basic numerals and pronouns, in the absence of paradigmatic morphology, is something the present writer has not seen in serious linguistic works in many years of experience. ${ }^{9}$ Sagart's work is much more serious than a mere amateurish venture, therefore he should widen his circle of evidence and include more stable basic vocabulary.

There is another point which is likely to raise some eyebrows among the most conservative historical linguists. Sagart consistently compares OC monosyllables or sesquisyllables to the second part of AN disyllables (more rarely trisyllables). It is true that reconstructions fairly frequently involve tailoring or theoretical abstractions, but the manipulation of real language data is not methodologically admissible in comparative linguistics:

[T] he criteria which have usually been considered necessary for a good etymology are very strict, even though there may seem to be a high a priori probability of relationship when similar words in languages known to be related are compared. In the case of lexical comparisons it is necessary to account for the whole word in the descendant languages, not just an arbitrarily segmented 'root,' and the reconstructed ancestral form must be a complete word (emphasis added). [...] it is obvious that much stricter criteria must be applied to word-comparison between language whose relationship is in question. (Goddard 1975: 254-5, also quoted in Campbell 2003).

In Sagart (2005), instead, we still find comparisons between PAN *-qem and OC *bim (cloud, cloudy), or between PAN *-taq and OC *atha? (earth), PAN *-zem and OC *btshim? (sleep), etc. Leaving aside the fact that this method has been proven inadequate in comparative linguistics, some etymologies need to be adjusted. As the present writer's expertise does not lie in Austronesian linguistics, this paper is not in a position to evaluate, let alone falsify Sagart's hypotheses concerning PAN or AN forms. Hence, this paper will refrain from offering judgements about Austronesian.

\footnotetext{
${ }^{8}$ Sagart cites very few body parts, most of which are strange and problematic (i.e. there are terms such as 'palm' but we do not find 'hand,' there are 'brain' and 'head' but no 'heart' and 'belly.' We find 'woman breast' but no 'chest' in general.). First, the character fú 扶 does not mean 'palm' but 'assist.' In the Shuōwén it is glossed as zuǒ 左, with zuǒ 左 being a graphic variant of zuǒ 佐 'assist.' Second, in *punuq 'brain' we find an unaccounted for syllable *pu-, while in *quluH 'head' *qu- is unmatched. *Kakay 'foot' finds "correspondence” only with Burmese, not with Chinese.

${ }^{9}$ It is well known since the times of Johannes de Laet (1581-1649) that basic vocabulary consists of numbers one to ten, kinship terms, body parts and natural terms.
} 


\section{A look to etymologies and lexical comparisons}

In historical linguistics, the very notion of 'basic vocabulary' has played a major role as one source of evidence for genetic relationship. Of course, lexical similarities are not enough, and the testimony of morphological processes and sound correspondences is also required. Etymology, intended as the "historical search for earlier stages in languages and the origin of words" (Campbell, Poser 2008: 15), is also an important tool to establish linguistic relationship. During his academic career, Sagart (especially 1999) has provided many valid etymologies for OC. Nevertheless, in his lexical comparison between OC and PAN (2005), we find some farfetched etymologies which cannot throw light on sound correspondences. A few examples are given below:

(1) yīn 陰: First of all, yīn 陰 does not mean 'cloud,' like in modern compounds, e.g., yīn tiān 'cloudy day,' but 'dark.' The Shuōwén glosses it as àn 闇, a graphic variant of the homophonous character àn 暗 'dark.' According to the Shiming, a Chinese dictionary compiled during Eastern Hàn times (25-220 AD) which employed phonological glosses, yìn 陰 has the same meaning of yīn 蔭 'shade.' The normal and neutral OC equivalent for 'cloud' is yún 云, and a comparison with it would make far better sense, because yin 陰 appears to be, instead, a descriptive predicate referring to shade.

(2) dàn 黮: Sagart (2005:164) compares PAN *-lem with OC *alïm? 'dark.' The first problem which this author finds in this comparison lies in the semantic domain. The Chinese character dàn 黮 'dark' is glossed as sāngshèn zhī hēi 桑葚之黑 'mulberry black.' Another explanation is offered by the Guăngyùn, where we find that the character means 'dark cloud' (yún hēi 雲黑). The second problem is that this rather rare character, which to the best of this author's knowledge appeared for the first time in the spurious part of Zhuāngž ( $3^{\text {rd }}$ century BC), is hardly considerable a "basic lexeme." The third problem is that we are presented with an unaccounted-for segment (if we exclude that another part of the PAN word has not been compared), i.e. OC ${ }^{*}-2$ vs PAN *-0? In the opinion of the present writer, this could be instead a good place to suggest that, perhaps, the words dàn 黮 and shèn 葚 are etymologically related (they share the same phonetic component and essentially differ by type A/B syllable, which possibly reflects an old morphological connection). If so, it is most likely that this word for 'dark' simply goes back to 'mulberry,' further complicating Sagart's Austronesian comparison. It must be remembered that this would not be the only case of a colour term which seems to have emerged from an object or from a surface property. For instance, the Sanskrit term for 'red,' rudhirá (< PIE * $h_{1} r u d^{h}$ rós), is applied equally to the colour 'red' and 'blood,' suggesting that, perhaps, this colour term emerged from the word for blood. This could also be true for the words dàn 黮 and shèn 葚.

(3) fú 扶: As stated above, the character fú 扶 (OC: *m- $[p](r) a)$ does not mean 'palm' but 'assist.' In the Shuōwén it is glossed as zuǒ 左, with zuǒ 左 being a graphic variant of zuǒ 佐 'assist.' Sagart (2009) insists that this word is cognate to Benedict's PTB * $p a>p w a$ 'palm,' which makes it a Sino-Tibetan word, but this writer still remains unconvinced. The neutral OC equivalent for 'palm' is zhăng 掌 (OC: *[k.t]aך?), and is evidently unrelated to PAN *dapa.

These few errors show nonetheless a certain negligence on Sagart's part in his investigation of textual evidence. This writer thinks that the few remarks above suffice to demonstrate that a part of the data provided by Sagart (2005) sometimes contains rarely used or polysemantic words that should not be considered "basic lexicon"; at other times, the alleged cognancy appears to be semantically loose or imprecise. 


\section{A closer look to stan morphology and sound correspondences}

In his famous work on comparative linguistics, Georg von der Gabelentz (1891: 168) stated that "Sprachvergleichung ohne Lautvergleichung ist gedankenlose Spielerei." Every competent linguist agrees wholeheartedly with this statement, and so does Sagart (2005). Unfortunately, some of the sound correspondences which should prove in detail the existence of the STAN superphylum are not as regular as they might seem from a first look. It is true that, in Sagart (2005), sound correspondences appear to be generally genuine and quite regular, but there are also problems which deserve a mention (Cf. Tab. 1):

(1) OC glottal stop / / seems to correspond to PAN ${ }^{*}-q,{ }^{*} H_{1}$ and ${ }^{*} H_{2}$, but sometimes it is unmatched, e.g., PAN *qiCeluR : OC ${ }^{*}{ }^{*}$ Ca-lo[r]l 'egg,' PAN *-lem : OC *alim? 'dark,' PAN *di :

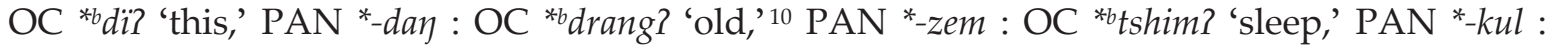
OC ${ }^{*}[k](r)_{o}[n]$ ? 'curled,' etc.;

(2) PAN velar nasal $/ \eta /$ in one case corresponds to OC ${ }^{*}-\eta$ and ${ }^{*}-k$ without explained con-

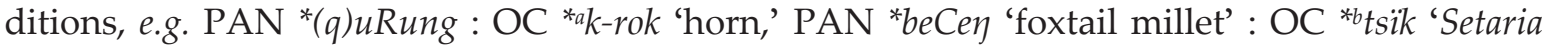
italica'; PAN *siNay : OC *blang 'sunlight,' etc.;

(3) PAN final syllable initials ${ }^{*}-N$ - and ${ }^{*}-l$ - correspond to OC ${ }^{*} l$ - and ${ }^{*}(h) l$ - without explained conditions, e.g. PAN *siNay : OC *blang 'sunlight,' PAN *daNum 'water' : OC *bt-hlïm? 'liquid,' PAN *b[e]lung : OC *along 'cave,' PAN *bulay: OC *bm-la[r] 'snake,' PAN *quluH $H_{1}$ : OC ${ }^{*} h l u$ ' 'head,' etc.;

(4) as argued before, AN roots occur only in combination with an initial syllable, therefore it is questionable to compare only the last syllable of PAN with the entire OC word, e.g. PAN *kupit: OC *apit 'close.'

Some points deserve a few remarks. First, the latest version of OC reconstruction (Baxter, Sagart 2014) seem to reject some of Sagart's earlier proposals. For example, 'far' is reconstructed - rightly in this author's opinion - with a final glottal stop which is unmatched in PAN. Second, if we accept the fact that Type A syllables had pharyngealised initials, then we must be aware that we are dealing with two different phonemes: thus, PAN ${ }^{*} t$ - may correspond to OC ${ }^{*} t-,{ }^{*} t^{h_{-}},{ }^{*} t^{\varepsilon_{-}}$and ${ }^{*} t^{h^{-}}$. This might be plausible, and this author does not exclude a priori these sound correspondences, but we must remember that plausibility by no means constitute proof ( $a$ posse ad esse non valet consequentia), and that the alleged sound correspondence, though somewhat regular, is quite unusual. Third, the Chinese character hán 含 'to hold in mouth' deserves a special mention. This polyseme is reconstructed with a loosely attached iambic prefix ${ }^{*} \mathrm{C} \partial$ - plus another ${ }^{*}-m$ - affix before the initial consonant ${ }^{*}-k^{\delta}$ - which find no internal support. The new reconstruction undoubtedly matches much more the reconstructed PAN form, ${ }^{11}$ however comparative evidence should not take the place of internal reconstruction. In historical linguistics it is not always recommendable to reconstruct morphemic boundaries in the language $X$ on the basis of the same or of a similar morpheme which can be found on its relative language $\mathrm{Y}$, let alone when the genetic relationship has yet to be established.

${ }^{10}$ A reviewer has pointed out to me that the OC ${ }^{*}-r$ - infix in this reconstruction is problematic, and that the

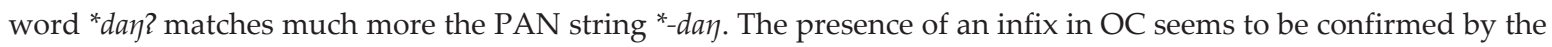
dialects of Xiàmén and Cháozhōu, where this word is respectively pronounced as $t i \eta^{6}$ and $t s i a \eta^{4}$. This writer finds no elements here that would require us to reconsider Baxter and Sagart's reconstruction.

${ }^{11}$ Another very important point needs to be clarified: in many cases striking similarities prove nothing. In the meantime, there are cases where real cognancy has been rendered almost unrecognisable based on today's word shape by the accumulated multiplicity of sound changes. For example, Armenian erku, Italian due and German zwei 'two' share a common origin, despite their strikingly different shape. This is not to imply that Sagart is not aware of this fact, but that striking similarities between languages do not automatically imply genetic relationship. 


\begin{tabular}{|c|c|c|c|}
\hline Gloss & PAN & OC (Sagart 2005) & OC (Baxter \& Sagrt 2014) \\
\hline body hair & *gumuN & ${ }^{*} \mathrm{~b} \mathrm{mu}[\mathrm{r}]$ & ${ }^{*} \mathrm{mr}[\partial][\mathrm{r}]$ \\
\hline egg (dialectal) & ${ }^{*}$ qiCeluR & ${ }^{* a} \mathrm{C} ə-\mathrm{lo}[\mathrm{r}] ?$ & *k.ror? \\
\hline snake & *bulay & ${ }^{*} \mathrm{~b} \mathrm{~m}-\mathrm{la}[\mathrm{r}]$ & ${ }^{*}$ Cə.1Aj \\
\hline sunlight & *siNan & *blan & *lan \\
\hline water & *daNum & *bt-hlïm? (liquid) & ${ }^{*} \mathrm{th}^{\mathrm{h}}[\partial] \mathrm{m} ?$ \\
\hline flow & *qaLur & *bhlu[r] (water) & *s.tur \\
\hline horn & *(q)uRung & *ak-rok & ${ }^{*} \mathrm{C} .[\mathrm{k}]^{\text {`rok }}$ \\
\hline chew & *paqpaq & ${ }^{* a m-p a 2-s}$ & ${ }^{*}[\mathrm{~b}]^{\uparrow}$ ras \\
\hline cut off & ${ }^{*}[\mathrm{p}, \mathrm{b}]$ utul & $*$ ato $[\mathrm{r}, \mathrm{n}]$ & *t'on?-s \\
\hline far & ${ }^{*}$ ma-dwiN & ${ }^{* b} \mathrm{wa}[\mathrm{r}, \mathrm{n}]$ & ${ }^{*}$ C.gwan? \\
\hline high & *-kaw & *akaw & ${ }^{*}$ Cə.kईaw \\
\hline hold in mouth & *gemgem & *ä̈m (in mouth) & ${ }^{*} \mathrm{C} \partial-\mathrm{m}-\mathrm{k}^{\S}[\partial] \mathrm{m}-\mathrm{s}$ \\
\hline curled & *-kul & ${ }^{* b} \mathrm{~N}-\mathrm{k}(\mathrm{h}) \mathrm{ro}[\mathrm{r}, \mathrm{n}]$ & $*[\mathrm{k}](\mathrm{r}) \mathrm{o}[\mathrm{n}] ?$ \\
\hline speak & *kawaS & ${ }^{*} \mathrm{~m}$-kw-r-at-s & ${ }^{*}[g]^{\text {ws }}$ rat-s \\
\hline bone & *kukut & *akut & ${ }^{*} k^{s}$ ut \\
\hline head/brain & *punuq & *anu? & $\left.{ }^{*} \mathrm{n}^{\S}[\mathrm{u}]\right\}$ \\
\hline elbow & ${ }^{*} \operatorname{siku}\left(\mathrm{H}_{2}\right)$ & *bt-r-ku? & $* t-[k]<r>\mathrm{u} ?$ \\
\hline hot & *qa(i)nget & ${ }^{*}$ nget & *C.nat/C.net \\
\hline put together & *pulung & *along & ${ }^{*} \mathrm{l}^{\text {I }}$ on \\
\hline ruin & ${ }^{*} \mathrm{r}[\mathrm{i}] \mathrm{bas}$ & *bbet-s & $*[b] e[t]-s$ \\
\hline chicken & *kuka & *ake & ${ }^{*} \mathrm{k}^{\S} \mathrm{e}$ \\
\hline robe & *sabuk & *bbuk & *[b]ək \\
\hline broom & ${ }^{*} \mathrm{CapuH}_{1}$ & *bt-pu? & $*[$ t.p]ə? \\
\hline Setaria & *beCeng & *btsïk & $*[\mathrm{ts}] \partial \mathrm{k}$ \\
\hline paddy/rice/grain & *Sumay & ${ }^{* a m i j}$ m & *(C.) $\left.\mathrm{m}^{\{}[\mathrm{e}] \mathrm{j}\right\}$ \\
\hline stopper & *sensen & *a sïk & ${ }^{*}[\mathrm{~s}]^{\S} \partial \mathrm{k}$ \\
\hline
\end{tabular}

Tab. 1. Unmatched sound correspondences between PAN and OC

Sagart's discussion on shared morphology, though very interesting - and in some cases even eye-opening - sometimes seems far-fetched. PAN nominaliser and goal focus marker - $x$ finds correspondence only in Tibetan and Lepcha nominalising suffix $-n$, there is nothing whatsoever similar in Chinese. It is very interesting, instead, that Early Middle Chinese had contrasting pairs of transitive verbs with voiceless stop initials versus intransitive verbs with voiced stop initials, such as 斷 *twan 'to cut' and *dwan ${ }^{12}$ 'broken off.' EMC intransitive voicing is thought to reflect an OC prenasalised prefix ${ }^{*} N$ - (Sagart 1994, 1999, 2003, 2005; Baxter, Sagart 2014). This seems to correspond to PAN actor focus prefix and infix ${ }^{*} m-/-m-.{ }^{13}$ Leaving aside

12 This author utterly rejects the usual practice, which seems to date back to Karlgren (1889-1978), of omitting asterisks with Early Middle Chinese forms. Even though the transcribed Late Middle Chinese (LMC) systems are coherent and agree with each other, EMC phonological system still remains highly theoretical, for it represents the literary reading of characters according to an assemblage of northern and southern dialects from various epochs. Hence, it represents a mixtum compositum and not a real language. On the other hand, the alphabetic and segmental scripts of written Old Tibetan can phonetically attest Late Middle Chinese forms, which thus require no asterisks.

${ }^{13}$ The parallel is surely very suggestive, but it is so if and only if we remain confined within the framework of Sagart's hypotheses. In other reconstruction systems, such as Baxter (1992) or Starostin (1989a), there is no *N- 
the fact that Blust (1995: 287) finds problematic the correspondence between PAN "stative/ attributive" marker ${ }^{*} m a$ - and OC transitive/intransitive prefix ${ }^{*} N-$, it must be remembered that the transitive and intransitive prefixes in Sino-Tibetan do not always occupy the same slots of PAN actor focus prefixes and infixes. Furthermore, it must be stressed that we are dealing with single phonemes for both PAN $\left({ }^{*} m-/-m-\right)$ and OC $\left({ }^{*} N-\right)$, and thus the risk of chance resemblance is dramatically high, especially when these isolated morphological markers (which can also be borrowed) are not integrated into a paradigmatic series. ${ }^{14}$ Moreover, we need to remember that grammatical affixes tend to utilise only a subset of consonants and vowels, and typically this subset is made up of less marked segments (Campbell, Poser 2008: 189). In particular, as Maddieson (1984: 70) informs us, nasals are often found in grammatical morphemes because they "are rarely subject to confusion with other types of consonants" (quoted also in Campbell, Poser 2008: 218). Comparisons between PAN instrumental/beneficiary focus prefix ${ }^{*}$ si- and ST valency-increasing ${ }^{*} S$ - is instead very suggestive. Nevertheless, we need to remember that the use of prefixes is a typologically commonplace, and that they can be easily explained in terms of areal typology, contacts or mere accident (cf. Tab. 2).

In brief, the evidence presented in favour of STAN is circumstantial and can easily be explained by non-genetic factors, therefore more effort is needed to guarantee a more solid plausibility for the proposed genetic relationship.

\begin{tabular}{c|c|c}
\hline \multirow{2}{*}{ pronominal affix } & Proto-Eastern Miwokan & Late Common IE \\
\cline { 2 - 3 } & Declarative suffixes & Secondary affixes (active) \\
\hline $1 \mathrm{sg}$ & ${ }^{*}$-m & ${ }^{*}$-m \\
\hline $2 \mathrm{sg}$ & ${ }^{*}$-s & ${ }^{*}$-s \\
\hline $3 \mathrm{sg}$ & ${ }^{*}-\varnothing$ & ${ }^{*}-\mathrm{t}<{ }^{* *} \varnothing$ \\
\hline $1 \mathrm{pl}$ & ${ }^{*}$-mas & ${ }^{*}$-me $(\mathrm{s}) /$-mo(s) \\
\hline $2 \mathrm{pl}$ & ${ }^{*}$-to-k & ${ }^{*}$-te \\
\hline
\end{tabular}

Tab. 2. Coincidence between Proto-Eastern-Miwokan and Late Common IE (quoted from Campbell, Poser 2008: 188).

To sum up, Sagart's (2005, 2011a) lexical comparisons, sound correspondences and shared morphological derivations present no robust evidence which would require us to reconsider our current understanding of both the Sino-Tibetan and the Austronesian families. ${ }^{15}$

prefix we can compare with PAN * $m$-. For example, what in Sagart (and later in Baxter and Sagart 2014) has been reconstructed as *N-qwh $r a$ 華 'to flower,' in Baxter (1992) is *wra, in Schuessler (2009) is * $(g)$ wrâ, and in Norman (2014) is * gwray. They are all respectable reconstruction systems, and yet in none of them the prenasalised ${ }^{*} N$ - infix is reconstructed. Even those scholars who are broadly sympathetic with Sagart's theories are not persuaded by the ${ }^{*} N$ - infix (Mei 2012: 14-16). In addition, transitivity is normally expressed syntactically without morphology.

${ }^{14}$ In addition, there is another issue which does deserve a brief comment. The reduction to monosyllables and the maintenance of prefixation and infixation are serious issues, but just how short these issues are argued in Sagart (2005) is incredibly stunning. This writer thinks that Sagart's paper, with its fifteen pages to fill, should have dwelt a bit more on this serious problem, which instead is crammed into a mere eleven lines. In short, Sagart (1993, 2005) argues that only polysyllabic words were affected by phonological erosion, so that monosyllables could then act as refuges for prefixes and infixes. The present writer knows no other attested case of phonological erosion where the sound change was "aware" of morpheme boundaries. To sum up, this writer finds this ad-usum-delphini explanation of a serious phonological issue-which this author had pinned his hopes on-quite disappointing.

${ }^{15}$ A colleague from Taipei has drawn my attention toward another 210-words list available on the internet: https://abvd.shh.mpg.de/austronesian/language.php?id=331 (University of Auckland, New Zealand). Setting aside that we find "nursery words" such as 'mother' and 'father,' this author finds several problems with the semantic 


\section{STAN Urheimat and Proto-STAN speakers}

As any good textbook for historical linguistics will teach with ample and documented historical examples, language reconstruction is not a mere teleological exercise, and comparative linguistics does not develop in a vacuum. Every language has its own history, and the speakers of that language are culturally, socially and politically connected with the history of that language. Therefore, when the linguists start their investigation with the language of a people, they also need to find out when and where this people started their journey before setting in a given part of the world. In order to complete this task, collective work and dialogue between specialists from different domains of academic research is needed. ${ }^{16}$

Sagart presents many competing and stimulating ideas, which, though bring him into conflict with many Austronesianists, deserve special attention. In his earliest proposals (Sagart 1993: 2), Sagart first suggested that STAN should be associated with the Dàwènkǒu culture (4100-2600 BC) of today Shāndōng province. However, more recently, Sagart (2011) argues that the Yăngsháo culture (5000-300 BC), a Neolithic culture which existed extensively along the Yellow River, corresponds to Proto-STAN homeland. It is interesting to see how Sagart's depicted picture fits in with different approaches. This writer thinks that Sagart's explanation of the historical and archaeological facts is very interesting but, unfortunately, not without problems.

First, it contrasts with the general scenario about the origin of PST people. The PST Urheimat seems to have been somewhere on the Himalayan plateau, where the great rivers of East and South-East Asia have their source (Matisoff STEDT, Blench \& Post 2013). Furthermore, the Shāng dynasty (1600-1046 BC) probably originated somewhere near the Ėrlígăng cultural frontier, while the Zhōu dynasty (1046-771 BC) is associated with the Guāngshè culture of the second millennium BCE. ${ }^{17}$ Now, if we accept Sagart's scenario, we are forced to accept the fact

of many words. A few examples will suffice to confirm this point. The character jiăo 腳 means 'foot' only in modern Chinese. The Shuōwén glosses it as jìng 脛 'calf of leg,' or even 'belly.' In the $64^{\text {th }}$ Chapter of Lăož there is a phrase whose meaning in English is "a travel of a thousand li starts with a single step (literally "under the foot")," which in Chinese is rendered as qiānľ̌ zhī xíng sȟ̀ yú zúxià 千里之行始於足下 and not as *qiānlǐ zhī xíng shǐ yú jiăoxià *千里之行始於腳下. The character kòu 寇, arguably a quite rare word, doesn't mean 'to steal' in OC, which is rather expressed with the older and more common form dào 盜, but 'to invade.' In the Yànž̀ chūnqiū [Annals of the Master Yan], a work which dates back no earlier than the III Century BCE, there is a passage which says: "The people who grow in Qi do not steal, they become burglars when they are [in the State of] Chu." In Chinese this phrase is written as mín shēngchăng yú Qí bù dào, rù Chǔ zé dào 民生長於齊不盜, 入楚則盜. It is clear that even in Late Old Chinese the dominant form for 'to steal' was still dào 盜 and not kòu 寇. In other words, this author finds the alleged cognancy highly questionable, for it is made up of obscure, polysemantic, rare and imprecise words.

${ }^{16}$ This, of course, does not imply that genetic relationship between languages can be established on extralinguistic grounds. Rather, as Gabelentz (1891: 157) has remarked: "Das einzig untrügliche Mittel, eine Verwandtschaft zu erkennen liegt in den Sprachen selbst.”

${ }^{17}$ Moreover, we must make one point clear at the outset: the study of Ancient China is perennially distorted by the desire, natural enough itself, of discovering not the origin of the civilisations in China, but the origin of the civilisation of China (Bagley 1999: 135), if this imprecise and rather modern term really means anything. We need to be aware that a Neolithic site in present-day Chinese territory was not necessarily the homeland of the so-called Huáxià people, an entity never well-defined but always imagined in quasi-historicistic terms drawn from later periods, or of some Chinese-speaking people. However, many Chinese archaeologists, instead of working back from definite evidence, starts with the assumption of the uninterrupted cultural unity of China and try to force all the archaeological discoveries to fit in with the traditional narrative (Jia 1980; Wu 1989; Liu \& Xiu, 2007; Wu et al. 2016). It follows that we are left with the strong impression that they are searching continuously and desperately for any scrap of data that can be taken as evidence to support the traditional view. This is not to imply that Sagart was driven into this cul-de-sac, but that the archaeological picture in China is not as clear as the general audience might imagine. 
that Proto-STAN inhabitants spoke their proto-language in the Hénán, Shănxī and Shānxī regions around $5000 \mathrm{BCE}$, and that PAN began to break up within the Taiwan Straits a millennium later, while PST people, essentially at the same time, break up into two branches, one of which (Proto-Sinitic) started their journey from the Himalayas and came back again in the vicinity of modern Zhèngzhōu, Pánlóngchéng and Yănshī cities, basically where it all began. This author may be not alone in thinking that this scenario is highly improbable. Sagart's solution to this problem is as follows: after the break up of Proto-STAN, the Western group (i.e. PST) developed in situ. Nevertheless, despite Sagart's efforts to link PST to Yăngsháo culture, this scenario remains unproven. Yet, how such identifications can be reasonably made in first place, given that we have no linguistic evidence of PAN, PST and Proto-Sinitic speakers anywhere on the Asian continent until, respectively, a millennium and three millennia later, we do not learn. Moreover, the bases for distinguishing Proto-STAN from PAN or PST are also unknown to us. Although Sagart's scenario may be true, from the viewpoints of linguistics and human migrations this interpretation of the Proto-STAN Urheimat remains fundamentally problematic and tells us little about linguistic interactions and further migrations of PAN and PST speakers.

Sagart (2005, 2011a, 2016), in addition to archaeological researches, cites also anthropological and genetic studies in support of his thesis. In this author's opinion, these researches may be a useful tool, since they can - and they do - throw some light on prehistoric migrations. Nevertheless, we must remember that language is independent of phenotypic traits, because human groups change their languages for different reasons in different epochs, and biological findings have been irrelevant, in detecting language relationship, throughout the entire history of linguistics. To sum up, although genetic studies may wink at Sagart's hypotheses (cf. Ko et al. 2014), ${ }^{18}$ what this discipline is able to tell us is that contemporary populations do show some connections based on genetic flow, which, with all due respect to these serious scholars, we already knew. What instead they are not able to tell us, on a firm footing, is that the ancestors of these populations were speaking the same language more than seven millennia ago. Nevertheless, based on the origin of the haplogroup E, which - Ko et al. (2014) say is developed out of the haplogroup M9 on the south-east coast near Fúzhōu (c. 8,136-10,933 years ago), Sagart (2016) claims that this scenario directly supports the STAN theory. This writer may be mistaken, but what Ko et al.'s genetic assumption seems to confirm is, instead, the scenario depicted by Bellwood (1997: 241-42):

During the late fifth or fourth millennium BC colonists from the mainland of southern China (probably Zhejiang or Fujian) settled Taiwan (emphasis added) [...] During the third millennium BC colonists moved into Luzon, and the Malayo-Polynesian subgroup now began its separation from the other primary subgroups of Austronesian which remained on Taiwan [...] By at least 2000 BC ProtoMalayo-Polynesian began to break up, probably with settlement expanding in various directions into the southern Philippines, Borneo, Sulawesi and the Moluccas.

18 "At around the time when haplogroup E developed from M9 in the population that later carried it into Taiwan, the surrounding regions gave rise to M9a lineages that are now carried by Sinitic speakers. Thus, the Han, Liangdao Man, and Formosan haplogroup M9a/E lineages can be traced to an ancestral M9 mtDNA lineage (Figure 3). Additionally, the Tibetans have a high frequency of M9a lineages that is shown to have coalesced during the Neolithic and there is a hypothesized linguistic link between Sino-Tibetan and Austronesian languages" (Ko et al. 2014: 239). The problem with the use of genetic studies in linguistics is that they can be interpreted as a Rorschach test, where facts are analysed using complex algorithms, intuitive and generally preconceived interpretations, or both. For example, Oppenheimer (2004) used mtDNA molecular clock calculations to conclude that Polynesians are derived from Palaeolithic eastern Indonesians, denying thus the generally accepted "out of Taiwan" theory. This scenario was rejected by Bellwood (2008). 
The evidence of a migration from the Shāndōng Peninsula to south-east China coasts is lacking. The only evidence Sagart has is that foxtail millet and proso millet (two of the main Austronesian cereals) are unknown archaeologically in the Yangtze valley and south of it. This view is only partially correct. First, the earliest domestication of foxtail millet took place in the middle of Císhān culture (6500-5000 BC), which originated in modern Héběi (Stevens et al. 2016). Second, foxtail millet is also thought to have reached Primorsky Krai (Eastern Siberia) around 3620 BCE (Kuzmin, 2013): should we include Eskimo-Aleut languages ${ }^{19}$ into STAN, as well? Third, proso millet (panicum miliaceum) may have been domesticated independently in both Transcaucasian areas and East-Asian areas. Thus, the so-called "northern Chinese look" of early Austronesian agriculture does not prove convincingly the STAN hypothesis.

Furthermore, in support of his thesis, Sagart pointed out that those Neolithic cultures, which he identified as Proto-STAN speakers, practised tooth avulsion (2011a: 147). This is extremely stimulating but, in this author's opinion, more attention to the anthropological works of the specialists of the field would have saved him from establishing a cause-and-effect relationship. Tooth avulsion is a worldwide practice which is still largely diffused today in SubSaharan Africa. ${ }^{20}$ For these reasons, all these uncertainties give the present writer the impression that the STAN hypothesis is still standing infirmly on one leg.

\section{Competing hypothesis: STAN vs Sino-Indo-European}

Another criticism that has been levelled against STAN (Blust 1995) and that has apparently remained unanswered is that of competing hypothesis, which involves mutual exclusivity (i.e. if we accept, say, Sino-Indo-European or Sino-Caucasian, then STAN is an invalid superphylum and vice versa). In the specific case of Chinese, a panoply concerning a wider affiliation of Sinitic has been proposed at least since the 19th century. Despite the interesting and quite brave attempts of grouping Sinitic with other families there has been no general agreement on any of these stimulating or rather quite speculative proposals. For some scholars (e.g., Beckwith 2002), the most promising proposal is the Sino-Indo-European hypothesis (Pulleyblank 1995, 1996), which is the taxonomic affiliation that argues for the connection between Indo-European and Chinese (or even Sino-Tibetan). Publications about this subject vary from amateurish attempts (Ulenbrook 1967, Chang 1988, Tan 2001, Zhōu 2002a, 2002b, Wei 2005b) to serious linguistic works (Pulleyblank 1996). ${ }^{21}$ Nevertheless, it will be briefly demonstrated in this paragraph that (1) all these attempts are situated in the same realm of nondemonstrable relationship, albeit some works are undoubtedly different in quality; (2) they are not better than the STAN hypothesis, actually much worse. ${ }^{22}$

19 Eskimo-Aleut languages are now spoken in north-east Siberia. However, Vovin (2015) suggested that, since Northern Tungusic languages have loanwords which are not found in Southern Tungusic, the Eskimo-Aleut was once much more widely spoken in eastern Siberia. This author agrees wholeheartedly with Vovin's view.

${ }^{20}$ In many cultures of Ethiopia, Sudan and East Africa, tooth avulsion appears to be related to the medical beliefs of those cultures, since canine, for example, are believed to be responsible for diarrhoea, fever and other diseases in children. For further understanding, the reader can consult this very insightful on-line paper by Mutai et al. 2010: https://www.ncbi.nlm.nih.gov/m/pubmed/20476714/. For a more technical discussion see also Schwartz (1946).

${ }^{21}$ To be fair, both Chinese and Tibetan were wrongly regarded as Sanskrit, and thus as member of the IndoEuropean family, by Sir William Jones (1799a, 1799b).

${ }^{22}$ The genetic relationship of Chinese and Indo-European has been proposed in several articles published on Sino-Platonic Papers (SPP) - a journal generally worth of praise for its critical power which unfortunately has 
The Sino-Indo-European superphylum was mainly advocated by Pulleyblank $(1995,1996)$ on the basis of a somewhat identical ablaut system, viz. EMC * $a{ }^{*}$. Leaving aside the fact that Pulleyblank's EMC ablaut system is based on the erroneous interpretation of the rather obscure terms of nèizhuăn 'inner turn' and wàizhuăn 'outer turn,' ${ }^{23}$ we must remember that ablaut and vowel mutations are not typologically unusual features and are, instead, diffused in many worldwide languages, such as Semitic languages, etc. (Campbell 1997: 196). Long before Pulleyblank, Sapir $(1915,1925)$ had already noted similarities in ablaut and causative prefixes between Na-Dene and Sino-Tibetan. Nevertheless, these vocalic alternations could also be found in Sapir's "Penutian", a distinct language family. Therefore, the sort of structural "evidences" both Sapir $(1915,1925)$ and Pulleyblank $(1995,1996)$ had in mind can be easily explained as independently developed typological similarities rather than inherited traits. ${ }^{24}$

Many etyma discussed by Pulleyblank (1996) were accepted and expanded, though with very different reconstructions, by Beckwith (2002: 149-150). Unfortunately, Beckwith's reconstruction are not methodologically explicit. For example, he reconstructs forms such as MOC *mîna < *mbîna < *Cmbêna < PChi *Twêna for rǔ 汝 'you' (OC: *nar), or MOC *mîna < *mbîna <

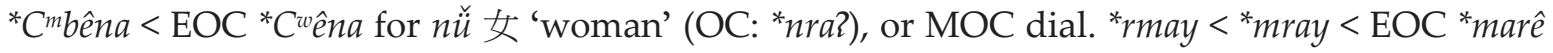
for hăi 海 'sea' (OC: * $m_{0}^{\text {`}} \partial$ 2). Beckwith's reconstructions routinely omit the final glottal stop [-2] which is strongly supported internally by many Sinitic languages. As it can be seen, all the real proposals of Sino-Indo-European that Beckwith might have had, unfortunately, are so buried under masses of obscure and unsupported reconstructions that it is quite hard to ferret them out.

given these quasi-scholarly works a positive judgement that undoubtedly suffers from excessive indulgence - by Zhōu (2002b, 2003) and Wei (2005a, 2005b). Nearly all these scholars say about Indo-European (IE) - a field in which they are evidently not at home-is false. The first methodical mistake which these scholars commit is that, in their attempt of inventing proofs where they do not exist, they do not compare Proto-Indo-European (PIE) with OC, but one of its many daughter languages with OC or with unsupported, obscure and invented proto-Chinese forms. They even claim to have discovered regular sound changes, such as OC ${ }^{*} m$ - and PIE ${ }^{*} m$-, ignoring the fact that in PIE the * $m$ - stem is an active declension. Furthermore, when Zhōu compares Chinese xùn 殉 (OC: *s.[G] $\left.{ }^{\mathrm{w}} \mathrm{i}[\mathrm{n}]-\mathrm{s}\right)$ [2002b: 4], which means 'be buried alive with the dead' and not 'die' as he writes, with Latin mor-t(and not *mort-), he is ignoring the fact that Latin mor-t- 'death' (and not 'die') derives from PIE * $m r$-tó-, which in turn is obtained by back derivation from the adjectival form * $n$ - $m r$-to- 'immortal.' Second, Zhōu's own theoretical views on IE studies seem to have congealed somewhere in the beginning of the 19th century, when it would have been quite difficult to find an Indo-Europeanist who would have accepted any need to reconstruct the laryngeal consonants. In part, the general resistance by those scholars outside IE linguistics to accepting laryngeals is excusable in view of their complexity and their "algebraic appearance," but a great amount of IE comparative linguistics is practically impossible without them. What Wei (2005b) adds to Zhōu's dissertations is nothing but a further list of lexical comparisons riddled with incorrect etymologies, Wortakrobatik and other blatant errors. Given their lack of understanding of IE linguistics (see, e.g., Wei 2005b: 1-72, Zhōu 2002b: 6, 2003: 3-17), it would seem that trying to make them understanding that, say, PIE *-t- was not an isolated marker which can be paralleled with the OC entering tone final *- $t$ but is one of the various PIE verbal nouns (Beekes 1995: 249-251) would be as futile a task as explaining PIE verbal morphology to primary school students. If one thinks that it is important to stimulate younger scholars to take part in the discussion, then detecting these mistakes is of utmost importance, because the general audience may fall prey of these amateurish ventures into a field which should not allow the likes of Zhōu and Wei free range.

${ }^{23}$ The two terms do not indicate any quality of the vowel. See Lŭ (1994: 271-283), still the best reference on the subject.

${ }^{24}$ For a positive evaluation of the Sino-Dene hypothesis see Bengtson (1994). A relationship between SinoTibetan and Athabaskan was also advocated by Shafer (1952). For an evaluation of Shafer's work, see Swadesh (1952a). 
Be that as it may, there is one aspect of long-range comparisons which was nowhere mentioned by Beckwith and Pulleyblank, and that is never mentioned by many macrocomparativists who frequently invoke the Indo-European model in order to validate their reconstruction: workers in IE linguistics have demonstrated with abundant documentation that someone dealing with, say, Italic may benefit from someone working on Celtic or on Greek. On the contrary, a philologist working with classical documentation in Old Chinese will not find the solution to, say, a verb problem by looking at Latin, Slavonic or Tocharian. ${ }^{25}$

Nevertheless, Beckwith (2002: 155) concludes his study on the subject in the following way:

In sum, it is certainly possible that Tibeto-Burman and Chinese are genetically related, but since the best-supported etymologies appear to be shared not only with Japanese-Koguryoic but also with Indo-European, it is likely that the relationship is either one of shared loan influence from the same donor or one of common descent from the same intrusive ancestor. Further study is therefore needed to determine more precisely the history of the interrelationship of these four families (emphasis added).

\section{Absit omen!}

\section{Closing remarks}

It is a truism in historical linguistics that non-relationship cannot be demonstrated. This author agrees wholeheartedly with this statement and, therefore, does not claim that Chinese (or Sino-Tibetan) and Austronesian cannot be related. Nevertheless, the genetic relationship between Sinitic and Austronesian still remains non-demonstrable due to the lack of common basic vocabulary, presence of unaccounted and unmatched segments and absence of productive sound correspondences. ${ }^{26}$ Sagart's argumentations, though interesting and stimulating, are still unable to offer valid morphological comparisons, let alone paradigmatic morphological comparisons. ${ }^{27}$ More emphasis is needed on morphology, both its overall structure and its idiosyncratic alternations. There are also other problematic issues, such as those concerning the STAN Urheimat and the competing hypotheses. This author, nonetheless, remains openminded to STAN, and would like to suggest that the STAN controversy can be improved by abandoning emphasis on common etymologies and shifting the attention to (1) more solid predictive-productive morphological correspondences; (2) questions of chronology; (3) questions regarding the STAN homeland; (4) rejection of competing hypotheses.

${ }^{25}$ The present writer has learnt this thing from Alonso de la Fuente's review of M. Robbeets (2016).

${ }^{26}$ Sagart argues that $\mathrm{AN}^{*}-q$ regularly corresponds to $\mathrm{OC}{ }^{*}-2$, the source of the marked member among the two basic Chinese tones. However, those PAN examples which account for OC tonogenesis seem to be valid only for Chinese, while they add nothing to AN linguistics. Therefore, in this author's opinion, they cannot be considered productive sound correspondences.

${ }^{27}$ It is true, however, that morphosyntactic considerations are rarely invoked (or invoked in a quite tentative way) in support of the Sino-Tibetan hypothesis as well. The differences between Sinitic and Tibeto-Burman are quite striking and not always convincingly explained. It is up to the competent linguist to work within these divergences in both of these two categories, and to demonstrate that a genetic relationship is likely to exist between the two groups. Nevertheless, more efforts in reconstructing PST is needed. One of the most recent attempts (South Coblin 1986) is laudable but does contain methodological peculiarities. For example, far too many of South Coblin's "reconstructed" proto-forms consist of long string of phonemes which eventually merged into zero in the received daughter languages. The best treatment of the family, especially from the Tibeto-Burman side, is Matisoff (2003). Unfortunately, from the Sinitic side, Matisoff adopted Karlgren's system, which is obsolete and now quite inadequate. Curiously, in Greenberg's opinion, Sino-Tibetan seems to be "one of the most solidly based and universally accepted linguistic stock in the world" (Greenberg 1996: 134). 


\section{Literature}

Alonso de la Fuente, J. A. 2016. Martine Robbeets (2015): Diachrony of verb morphology. Japanese and the Transeurasian languages. Diachronica 33(4): 530-537.

Bagley, Robert. 1999. Shang archaeology. In: M. Loewe, Edward L. Shaugnessy (eds.). The Cambridge history of ancient China: 124-231. Cambridge University Press.

Baxter, William H. 1992. A handbook of Old Chinese phonology. Berlin: Walter de Gruyter.

Baxter, William H., Laurent Sagart. 2014. Old Chinese: a new reconstruction. Oxford University Press.

Beckwith, Christopher. 2002. The Sino-Tibetan problem. In: Christopher Beckwith. Medieval Tibeto-Burman Languages: 113-157. Leiden: Brill.

Beekes, R. S. P. 1995. Comparative Indo-European Linguistics. An Introduction. Amsterdam: Benjamins.

Bellwood, Peter. 1995. Austronesian prehistory in Southeast Asia: homeland, expansion and transformation. In: Peter Bellwood, J. Fox, D. Tryon (eds.) The Austronesians: 96-111. Canberra: Australian National University.

Bellwood, Peter. 1997. Prehistory of the Indo-Malaysian Archipelago (2nd edition). Honolulu: University of Hawaii Press.

Bellwood, Peter. 2005. First farmers: The origins of agricultural societies. Oxford: Blackwell.

Bellwood, Peter. 2007. Southeast China and the Prehistory of the Austronesians. In: T. Jiao (ed.). Lost Maritime Cultures: China and the Pacific: 36-53. Hawaii: Bishop Museum Press.

Bellwood, Peter. 2008. Austronesian cultural origins: out of Taiwan, via the Batanes Islands, and onwards to western Polynesia. In: Alicia Sanchez-Mazas, Roger Blench, Malcolm D. Ross, Ilia Peiros and Marie Lin (eds.) Past human migrations in East Asia: matching archaeology, linguistics and genetics: 23-39. London: Routledge.

Bellwood, Peter. 2011. The checkered prehistory of rice movement southwards as a domesticated cereal - from the Yangzi to the equator. Rice 4(3-4): 93-103.

Benedict, Paul K. 1991. Austric: an 'extinct' proto-language. J. H. C. S. Davidson (ed.). Austroasiatic Languages: essays in honour of H. L. Shorto: 7-11. London: Psychology Press.

Bengtson, John D. 1994. Edward Sapir and the "Sino-Dene" Hypothesis. Anthropological Science 102(3): $207-230$.

Blench, Roger M. 2012. Almost everything you believed about the Austronesians isn't true. In: Dominik Bonatz, Andreas Reinecke, Mai Lin Tjoa-Bonatz (eds.). Crossing Borders: Selected Papers from the 13th International Conference of the European Association of Southeast Asian Archaeologists, Vol. 1: 122-142. Singapore: NUS Press.

Blust, Robert A. 1995a. The prehistory of the Austronesian-speaking peoples: a view from language. Journal of World prehistory 9(4): 453-510.

Blust, Robert A. 1995b. An austronesianist looks at Sino-Austronesian. In: William S-Y. Wang (ed.). The Ancestry of the Chinese Language. Journal of Chinese Linguistics Monograph Series 8: 283-298. University Of California Press.

Blust, Robert A. 1996. The Neogrammarian hypothesis and pandemic irregularity. In: Mark Durie, Malcolm Ross (eds.). The Comparative Method reviewed: Regularity and irregularity in language change: 135-156. New York/ Oxford: Oxford University Press.

Blust, Robert A. 2003. Three notes on early Austronesian morphology. Oceanic Linguistics 42(2): 438-478.

Blust, Robert A. 2005a. Must sound change be linguistically motivated? Diachronica 22(2): 219-269.

Blust, Robert A. 2005b. The Oceanic languages. Oceanic Linguistics 44(2): 544-558.

Blust, Robert A. 2008. Is there a Bima-Sumba subgroup? Oceanic Linguistics 47(1): 45-113.

Blust, Robert A. 2010. The greater north Borneo hypothesis. Oceanic Linguistics 49(1): 44-118.

Blust, Robert A. 2013. The Austronesian languages. Canberra: Asia-Pacific Linguistics.

Blust, Robert A. 2014. Some recent proposals concerning the classification of the Austronesian languages. Oceanic Linguistics 53(2): 300-391.

Bopp, Franz. 1841. Über die Verwandtschaft der malaisch-polynesischen Sprachen mit den indo-europäischen. Gelesen in der Akademie der Wissenschaften am 10. aug. und 10. dec. 1840. Berlin: Dümmler.

Branner, David P. 2000. Problems in comparative Chinese dialectology: the classification of Miin and Hakka. Berlin / New York: Walter de Gruyter.

Campbell, Lyle. 1997. Genetic classification, typology, areal linguistics, language endangerment, and languages of the north Pacific rim. In: Osahito Miyaoka, Minoru Oshima (eds.). Languages of the North Pacific Rim, Vol. 2: 179-242. Kyoto University.

Campbell, Lyle. 2003. How to show languages are related: Methods for distant genetic relationship. In: Brian D. Joseph, Richard D. Janda (eds.). The Handbook of Historical Linguistics: 262-282. Blackwell Publishing. 
Campbell, Lyle. 2013. Historical linguistics. Edinburgh University Press.

Campbell, Lyle, William J. Poser. 2008. Language classification. History and method. Cambridge University Press.

Chang, Tsung-Tung. 1988. Indo-European Vocabulary in Old Chinese. Sino-Platonic Papers 7: 1-54.

Conrady, August. 1896. Eine indochinesische Causativ-Denominativ-Bildung und ihr Zusammenhang mit den Tonaccenten: Ein Beitrag zur vergleichen-den Grammatik der indochinesischen Sprachen, Insonderheit des tibetischen, barmanischen, siamesischen und chinesischen. Leipzig: Otto Harrassowitz.

Conrady, August. 1916. Eine merkwürdige Beziehung zwischen den austrischen und den indochinesischen Sprachen. In: Aufsätze zur Kultur- und Sprachgeschichte vornehmlich des Orients: Ernst Kuhn zum 70. Geburtstage am 7. Februar, 1916: 475-504. München: Verlag von M. \& H. Marcus.

Driem van, George. 2001. Languages of the Himalayas: an ethnolinguistic handbook. Leiden: Brill.

Driem van, George. 2005. Sino-Austronesian vs. Sino-Caucasian, Sino-Bodic vs. Sino-Tibetan, and Tibeto-Burman as default theory. In: Yogendra Prasada Yadava, Govinda Bhattarai, Ram Raj Lohani, Balaram Prasain, Krishna Parajuli (eds.). Contemporary issues in Nepalese linguistics: 285-338. Kathmandu: Linguistic Society of Nepal.

Edkins, Joseph. 1871. China's Place in Philology: an Attempt to show that the Languages of Europe and Asia have a Common Origin. London: Trübner \& Co.

Gabelentz von der, Georg. 1901. Die Sprachwissenschaft. Aufl. Leipzig.

Goddard, Ives. 1975. Algonquian, Wiyot, and Yurok: Proving a distant genetic relationship. In: Dale M. Kinkade, Kenneth L. Hale, Otmar Werner (eds.). Linguistics and anthropology: in honor of C. F. Voegelin: 249-262. Lisse: The Peter de Ridder Press.

Greenberg, Joseph H. 1996. In defense of Amerind. International journal of American linguistics 62(2): 131-164.

Holman, E. W., C. H. Brown, S. Wichmann, A. Müller, V. Velupillai, H. Hammarström, S. Sauppe, H. Jung, D. Bakker, P. Brown, O. Belyaev. 2011. Automated dating of the world's language families based on lexical similarity. Current Anthropology 52(6): 841-875.

Hudson, Mark J. 1999. Japanese and Austronesian: an archeological perspective on the proposed linguistic links. In: K. Omoto (ed.). Interdisciplinary Perspectives on the Origins of the Japanese: 267-279. Kyoto: International Research Center for Japanese Studies.

Humboldt von, Wilhelm. 1836-1839. Über die Kawi-Sprache auf der insel Java, nebst einer einleitung über die verschiedenheit des menschlichen sprachbaues und ihren einfluss auf die geistige entwickelung des menschengeschlechts. Berlin: Druckerei der Königlichen Akademie der Wissenschaften.

Jia, Lanpo. 1980. Early man in China. Beijing: Foreign Languages Press.

Jones, Sir William. 1799a [delivered February 25, 1790]. Eighth anniversary discourse: on the Chinese. Asiatick Researches 2: 43-46.

Jones, Sir William. 1799b [delivered February 23, 1792]. Ninth anniversary discourse: on the origin and families of nations. Asiatick Researches 3: 418-435.

Kawamoto, Takao. 1977. Toward a comparative Japanese-Austronesian I. Bulletin of Nara University Education 26(1): 22-49.

Kawamoto, Takao. 1978. Minami kara kita Ninhongo. Tōkyō: Sanseidō.

Kawamoto, Takao. 1980. Nihongo no kenryū. Tōkyō: Kōdansha.

Kawamoto, Takao. 1984. Two sets of sound laws between Japanese and Austronesian. Bulletin of Joetsu University of Education 3: 31-50.

Kawamoto, Takao. 1993. Several similarities between Japanese and the Austronesian languages. Paper presented at the Conference on Asia-Mainland/Austronesian Connections, University of Hawai'i at Mānoa, May 10-13.

Kempler-Cohen, E. M. 2012. Austronesian cognates in Quechua - Part 1: Proto-Oceanic disyllabic cognates in Proto-Quechua. The Philippine Journal of Linguistics 43: 1-46.

Kortlandt, Frederik. 2010. Studies in Germanic, Indo-European and Indo-Uralic. Brill / Rodopi.

Krippes, Karl A. 1992. The genetic relationship between Japanese and Austronesian revisited. Ural-Altaische Jahrbücher 64: 117-130.

Ko, A. M. S., C. Y. Chen, Q. Fu, F. Delfin, M. Li, H. L. Chiu, M. Stoneking, Y. C. Ko. 2014. Early Austronesians: into and out of Taiwan. The American Journal of Human Genetics 94(3): 426-436.

Kuzmin, Y. V. 2013. The beginnings of prehistoric agriculture in the Russian Far East: Current evidence and concepts. Documenta Praehistorica 40: 1-12. 
Li, Paul Jenkuei. 1995. Is Chinese genetically related to Austronesian? In: William S-Y. Wang (ed.). The Ancestry of the Chinese Language. Journal of Chinese Linguistics Monograph Series 8: 93-112. University Of California Press.

Ľ̌, Xīnkuí [李新魁]. 1994. Lǐ Xīnkuí yǔyán xué lùnjí 李新魁語言學論集 [Lǐ Xīnkuí's selected works in Linguistics]. Běijīng: Zhōnghuá shūjú.

Liu, Li, Hong Xiu. 2007. Rethinking Erlitou: legend, history and Chinese archaeology. Antiquity 81(314): 886-901.

Maddieson, Ian. 1984. Patterns of sounds. Cambridge University Press.

Matisoff, James A. 2003. Handbook of Proto-Tibeto-Burman: system and philosophy of Sino-Tibetan reconstruction. University of California Press.

Mei, Tsu-Lin. 2012. The causative *s- and nominalizing ${ }^{*} \mathrm{~s}-$ in Old Chinese and related matters in Proto-SinoTibetan. Language and Linguistics 13(1): 1-28.

Mutai, J., E. Muniu, J. Sawe, J. Hassanali, P. Kibet, P. Wanzala. 2010. Socio-cultural practices of deciduous canine tooth bud removal among Maasai children. International dental journal 60(2): 94-98.

Ness, Immanuel. 2014. The global prehistory of human migration. John Wiley \& Sons.

Norman, Jerry. 2014. A model for Chinese dialect evolution. In: Richard VanNess Simmons, Newell Ann Van Auken (eds.). Studies in Chinese and Sino-Tibetan linguistics: Dialect, phonology, transcription and text: 1-26. Taipei: Institute of Linguistics, Academia Sinica.

Pietrusewsky, Michael. 1994. Pacific-Asian relationships: a physical anthropological perspective. Oceanic Linguistics 33(2): 407-429.

Pulleyblank, Edwin G. 1965. Close/open ablaut in Sino-Tibetan. Lingua 14: 230-240.

Pulleyblank, Edwin G. 1991. The ganzhi as phonograms and their application to the calendar. Early China 16: 3980.

Pulleyblank, Edwin G. 1995a. Why Tocharians? Journal of Indo-European Studies 23(3-4): 415-430.

Pulleyblank, Edwin G. 1995b. The historical and prehistorical relationships of Chinese. In: William S-Y. Wang (ed.). The Ancestry of the Chinese Language. Journal of Chinese Linguistics Monograph Series 8: 145-194. University Of California Press.

Pulleyblank, Edwin G. 1996. Early contacts between Indo-Europeans and Chinese. International Review of Chinese Linguistics 1(1): 1-25.

Reid, L. A. 1994. Morphological evidence for Austric. Oceanic linguistics 33(2): 323-344.

Rivet, Paul. 1925. Les mélano-polynésiens et les australiens en Amérique. Anthropos 20: 51-54.

Rivet, Paul. 1926. Les malayo-polynésiens en Amérique. Journal de la Société des Américanistes de Paris 18: 141-278.

Sagart, Laurent. 1990. Chinese and Austronesian are genetically related. Paper presented at the 23rd International Conference on Sino-Tibetan Languages and Linguistics, Arlington, October 1990.

Sagart, Laurent. 1993. Chinese and Austronesian: Evidence for a genetic relationship. Journal of Chinese Linguistics 21: 1-62.

Sagart, Laurent. 1994. Old Chinese and Proto-Austronesian. Oceanic Linguistics 33(2): 271-308.

Sagart, Laurent. 1995a. Some remarks on the ancestry of Chinese. In: William S-Y. Wang (ed.). The Ancestry of the Chinese Language. Journal of Chinese Linguistics Monograph Series 8: 195-223. University Of California Press.

Sagart, Laurent. 1995b. Comments from Sagart. In: William S-Y. Wang (ed.). The Ancestry of the Chinese Language. Journal of Chinese Linguistics Monograph Series 8: 337-372. University Of California Press.

Sagart, Laurent. 1995c. Questions of method in Chinese-Tibeto-Burman comparison. Cahiers de linguistique Asie orientale 24(2): 245-255.

Sagart, Laurent. 1999. The roots of old Chinese. Amsterdam / Philadelphia: John Benjamins Publishing Company.

Sagart, Laurent. 2001. Vestiges of Archaic Chinese derivational affixes in modern Chinese dialects. In: Hilary Chappell (ed.). Sinitic grammar: synchronic and diachronic perspectives: 123-142. Oxford University Press.

Sagart, Laurent. 2003. The vocabulary of cereal cultivation and the phylogeny of East Asian languages. Bulletin of the Indo-Pacific Prehistory Association 23(1): 127-136.

Sagart, Laurent. 2004. The higher phylogeny of Austronesian and the position of Tai-Kadai. Oceanic Linguistics 43(2): 411-44.

Sagart, Laurent. 2005. Sino-Tibetan-Austronesian: An updated and improved argument. In: Laurent Sagart, Roger Blench, Alicia Sanchez-Mazas (eds.). The peopling of East Asia: Putting together archaeology, linguistics and genetics: 161-176. London / New York: Routledge Curzon.

Sagart, Laurent. 2006. On intransitive nasal prefixation in Sino-Tibetan languages. Cahiers de linguistique Asie orientale 35(1): 57-70. 
Sagart, Laurent. 2008a. The expansion of Setaria farmers in East Asia. In: Alicia Sanchez-Mazas, Roger Blench, Malcolm D. Ross, Ilia Peiros and Marie Lin (eds.) Past human migrations in East Asia: matching archaeology, linguistics and genetics: 133-157. London: Routledge.

Sagart, Laurent. 2008b. Reply to Matisoff on the Handbook of Proto-Tibeto-Burman: System and philosophy of Sino-Tibetan reconstruction. Diachronica 25(1): 153-155.

Sagart, Laurent. 2009. PAn morphology in phylogenetic perspective. Paper presented at 11-ICAL (11ème conférence internationale sur la linguistique austronésienne), Aussois, June 22-25, 2009.

Sagart, Laurent. 2010a. Is Puyuma a primary branch of Austronesian? Oceanic Linguistics 49(1): $194-204$.

Sagart, Laurent. 2010b. Why does the Tai-Kadai word for 'ten' end in -t? Paper presented at the 23èmes Journées de Linguistique d'Asie Orientale, Paris, July 1-2, 2010.

Sagart, Laurent. 2011a. The homeland of Sino-Tibetan-Ausronesian: where and when? Communication on Contemporary Anthropology 2011(5): 143-147.

Sagart, Laurent. 2011b. How many independent rice vocabularies in Asia? Rice 4(3-4): 121-133.

Sagart, Laurent. 2011c. Sino-Tibetan-Austronesian: Making sense of non-final syllables. Paper presented at a symposium on Historical Linguistics in the Asia-Pacific Region and the Position of Japanese, Twentieth International Conference on Historical Linguistics Symposium, National Museum of Ethnology, Osaka, July 30, 2011.

Sagart, Laurent. 2013. The higher phylogeny of Austronesian: A response to Winter. Oceanic Linguistics 52(1): 249-254.

Sagart, Laurent. 2014. In defense of the numeral-based model of Austronesian phylogeny, and of Tsouic. Language and Linguistics 15(6): 859-882.

Sagart, Laurent. 2016a. The wider connections of Austronesian: a Response to Blust (2009). Diachronica 33(2): $255-281$.

Sagart, Laurent. 2016b. Liangdao Man and Austronesian origins. Journal of Chinese Linguistics 44(1): $239-241$.

Sapir, Edward. 1915. The Na-Dene Languages, a preliminary report. American Anthropologist 17(3): 534-558.

Sapir, Edward. 1925. The similarity of Chinese and Indian languages. Science 62(1607):xii.

Schmidt, Wilhelm. 1906. Die Mon-Khmer-völker: ein bindeglied zwischen Völkern Zentralasiens und Austronesiens. Braunschweig: F. Vieweg und Sohn.

Schwartz, J. 1946. The teeth of the Masai. Journal of dental research 25(1): 17-20.

Shafer, Robert. 1952. Athapaskan and Sino-Tibetan. International Journal of American Linguistics 18(1): 12-19.

Shafer, Robert. 1957. Note on Athapaskan and Sino-Tibetan. International Journal of American Linguistics 23(2): 116-117.

Shafer, Robert. 1969. A few more Athapaskan and Sino-Tibetan comparisons. International Journal of American Linguistics 35(1): 67-67.

Schuessler, Axel. 2009. Minimal Old Chinese and later Han Chinese: a companion to Grammata serica recensa. University of Hawaii Press.

South Coblin, Weldon. 1986. A Sinologist's handlist of Sino-Tibetan lexical comparisons. Nettetal: Steyler Verlag.

Starostin, S. A. 1984. Gipoteza o geneticheskix svjazjax sinotibetskix jazykov s enisejskimi i severnokavkazskimi jazykami. In: I. Vardul' (ed.). Lingvisticheskaja rekonstrukcija i drevnejshaja istorija Vostoka: 19-38. Moscow: Nauka.

Starostin, S. A. 1989a. Rekonstrukcija drevnekitajskoj fonologicheskoj sistemy. Moscow: Nauka.

Starostin, S. A. 1989b. Nostratic and Sino-Caucasian. In: V. Shevoroshkin (ed.). Explorations in language macrofamilies: 42-66. Bochum: Universitetsverlag N. Brockmeyer.

Starostin, S. A. 1991. On the hypothesis of a genetic connection between the Sino-Tibetan languages and the Yeniseian and North-Caucasian languages. In: V. Shevoroshkin (ed.). Dene-Sino-Caucasian Languages: 12-41. Bochum: Universitetsverlag N. Brockmeyer.

Starostin, S. A. 2005. Sino-Caucasian. Unfinished MS. Available online at: http://starling.rinet.ru (Tower of Babel Project).

Stevens, C. J., C. Murphy, R. Roberts, L. Lucas, F. Silva, D. Q. Fuller. 2016. Between China and South Asia: A Middle Asian corridor of crop dispersal and agricultural innovation in the Bronze Age. The Holocene 26 (10): 15411555.

Swadesh, Morris. 1952a. "Athapaskan and Sino-Tibetan." Review of Shafer 1952. International Journal of American Linguistics: $178-181$.

Swadesh, Morris. 1952b. Lexicostatistic Dating of Prehistoric Ethnic Contacts. Proceedings of the American Philosophical Society 96: 452-463.

Swadesh, Morris. 1955. Towards Greater Accuracy in Lexicostatistic Dating. International Journal of American Linguistics 21: 121-137.

Swadesh, Morris. 1971. The Origin and Diversification of Language. Ed. post mortem by Joel Sherzer. Chicago: Aldine. 
Tabbada, K., J. Trejaut, J. Loo, Y. Chen, M. Lin, M. Mirazon-Lahr, T. Kivisild, M. De Ungria. 2009. Philippine Mitochondrial DNA Diversity: A Populated Viaduct between Taiwan and Indonesia? Molecular Biology and Evolution 27(1): 21-31.

Tan, J. M. 2001. Hànyǔ cíhuì de jìn yuán tànmì 漢語詞彙的近源探秘. Běijīng: Yuanzineng Publishing House.

Ulenbrook, Jan. 1967. Einige Übereinstimmungen zwischen dem Chinesischen und dem Indogermanischen. Anthropos 3/4: 533-551.

Vovin, Alexander. 2015. Eskimo Loanwords in Northern Tungusic. Iran and the Caucasus 19: 87-95.

Wang, William S.-Y. (ed.). 1995. The ancestry of the Chinese language. Journal of Chinese Linguistics Monograph Series 8. University Of California Press.

Wáng, X. Q., X. Liú. 1896. Shìmíng shū zhèng bǔ 釋名疏證補. Shànghǎi gǔjí Publishing House.

Wei, J. L. 2005a. Review of Hànyǔ Yìn'ōuyǔ cíhuì brijiào. Sino-Platonic Papers 166: 1-22.

Wei, J. L. 2005b. Counting and Knotting: Correspondences between Old Chinese and Indo-European. Sino-Platonic Papers 162: 1-72.

Wolff, J. U. 2010. Proto-Austronesian phonology with glossary. Southeast Asia Program Publications. 2 vols. Ithaca, New York: Cornell University.

Wu, R. K. 1989. Gǔrénlèixué 古人類學. Běijīng: Wénwù chūbăn shè.

Wu, Q., Z. Zhao, L. Liu, D. E. Granger, H. Wang, D. J. Cohen, X. Wu, M. Ye, O. Bar-Yosef, B. Lu, J. Zhang. 2016. Outburst flood at 1920 BCE supports historicity of China's Great Flood and the Xia dynasty. Science 353 (6299): 579-582.

Zhōu Jíxù. 2002a. Hànyǔ Yìn'ōuyǔ cíhuì bǐjiào 漢語印歐語詞彙比較 [Word comparisons between Chinese and IndoEuropean]. Sìchuān Mínzú Publishing House.

Zhōu Jíxù. 2002b. Correspondences of the Basic Words between Old Chinese and Proto-Indo-European. SinoPlatonic Papers 115: 1-8.

Zhōu Jíxù. 2003. Correspondences of Cultural Words between Old Chinese and Proto-Indo-European. SinoPlatonic Papers 124: 1-19.

Zohary, D., M. Hopf, E. Weiss. 2012. Domestication of Plants in the Old World: The origin and spread of domesticated plants in Southwest Asia, Europe, and the Mediterranean Basin. Oxford University Press on Demand.

Дж. Орланди. К оценке сино-тибето-австронезийской гипотезы.

В статье проводится анализ и оценка гипотезы о возможном генетическом родстве между сино-тибетскими и австронезийскими языками, предложенной французским синологом Лораном Сагаром. Статья преследует не столько цель доказать или опровергнуть существование сино-тибето-австронезийской макросемьи, сколько проверить, соответствуют ли данные, собранные Сагаром в ее поддержку, стандартным критериям исторического языкознания. Помимо этого, обсуждается ряд вопросов, связанных с гипотетической прародиной сино-тибето-австронезийцев, в том числе в контексте таких конкурирующих гипотез, как сино-индоевропейская. Мы приходим к выводу, что подход, избранный Сагаром, недостаточно доказателен для такого рода сложных и противоречивых гипотез о дальнем языковом родстве.

Ключевые слова: сино-тибето-австронезийская гипотеза; сино-тибетские языки; генетическое родство языков; сравнительно-исторический метод. 